\title{
Processo evolutivo pastoral das irmandades nas Igrejas do Centro do Rio de Janeiro
}

Orientador: Prof. Abimar Oliveira de Moraes

Pesquisadora: Geysa Pereira de Magalhães

Fonte: $\mathrm{CNPq}$

\section{Introdução}

A pesquisa teve por objeto de estudo as Irmandades católicas inseridas no espaço geográfico nas Igrejas do Centro do Rio de Janeiro, planeando o processo histórico da comunidade cristã e evolutivo dos séculos XVII e XVIII, reunindo leigos responsáveis pelas expansões e devoções católicas, apresentando suas funções na presença das camadas sociais, nas manifestações exteriores da fé, nas disputas internas, entre o Estado e o poder eclesiástico. Seus tecidos bibliográficos se apresentaram nas estruturas étnica, social, cultural e religiosa, bem como na estratificação histórica-social-políticageográfica, com enfoque pastoral e suas teologias.

\section{Objetivos}

Investigar a atuação pastoral das Irmandades do Centro do Rio de Janeiro nos séculos XVII e XVIII, compreendendo o processo histórico e evolutivo pastoral, seu papel na construção da identidade do catolicismo, conhecer as atividades pastorais, suas influências, identificar seus agentes dando relevância à religião para a vida de uma sociedade e descobrir novas fontes. 